\title{
Effect of garlic (Allium sativum L.) stems on inflammatory cytokines, iNOS and COX-2 expressions in Raw 264.7 cells induced by lipopolysaccharide
}

\author{
Yong Hun Cho ${ }^{1}$, Hyeon Jeong Kim ${ }^{1,2}$, Dong In Kim ${ }^{1}$, Jae Yoon Jang ${ }^{1}$, Jae Hoon Kwak ${ }^{1}$, \\ Yu Hyeon Shin ${ }^{1,2}$, Yeon Gje Cho ${ }^{3}$, Bong Jeon $\mathrm{An}^{1 *}$ \\ ${ }^{1}$ Department of Cosmeceutical Science, Daegu Hanny University, Gyeongsan 38610, Korea \\ ${ }^{2}$ Institute of Technology, Herbnoori. Co., Ltd., Daegu 41581, Korea \\ ${ }^{3}$ School of Food Science and Biotechnology / Food and Bio-Industry Research Institute, \\ Kyungpook National University, Daegu 41566, Korea
}

\section{Lipopolysaccharide로 유도된 Raw 264.7 세포에서 마늘대 추출물(Allium sativum L. Stems)의 염증성 사이토카인 및 iNOS, COX-2 발현에 대한 효과 검증}

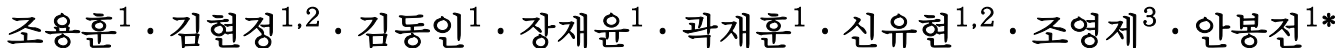 \\ ${ }^{1}$ 대구한의대학교 화장품약리학과, ${ }^{2}$ (주)허브누리 기술연구소, ${ }^{3}$ 경북대학교 식품공학부/식품생물산업연구소
}

Abstract

In this study, the anti-oxidant and anti-inflammatory activities of water extract (ASSW) and 70\% ethanol extract (ASSE) of Allium sativum L. stems were investigated using Raw 264.7 cells induced by lipopolysaccharide (LPS). ABTS radical scavenging activities of ASSW and ASSE at $1000 \mu \mathrm{g} / \mathrm{mL}$ concentration were $96.9 \%$ and $97.8 \%$, respectively. In order to investigate the potential anti-inflammatory effects of ASSW and ASSE, nitric oxide (NO), pro-inflammatory cytokines, interleukin-6 (IL-6), and tumor necrosis factor including a (TNF- $\alpha$ ), interleukin-1 $\beta$ (IL-1 $\beta$ ), and prostaglandin-E2 (PGE2) were measured. ASSW and ASSE at $100 \mu \mathrm{g} / \mathrm{mL}$ concentration showed inhibitory effects against NO production by $18 \%$ and $23 \%$, respectively. Production of IL-1 $\beta$ and IL-6 after treatment with ASSW and ASSE at $100 \mu \mathrm{g} / \mathrm{mL}$ decreased by approximately $28 \%$ and $15 \%$ for ASSW and $17 \%$ and $12 \%$ for ASSE, respectively. In addition, production of TNF- $\alpha$ after treatment of $100 \mu \mathrm{g} / \mathrm{mL}$ of ASSW and ASSE decreased by $24 \%$ and $23 \%$, respectively. In addition, the treatment of $100 \mu \mathrm{g} / \mathrm{mL}$ of ASSW and ASSE showed inhibitory expressions against PGE2 by $\mathbf{4 5 . 4 7 \%}$ and $\mathbf{3 3 . 8 7 \%}$, respectively. These results suggested that ASSE showed greater inhibitory activity than that of the ASSW by the suppression of inflammatory mediators, including NO, IL-6, TNF-a and PGE2 production, and the expressions of iNOS and COX-2 in macrophages. In conclusion, ASSW and ASSE may have some ancillary effects on inflammatory factors as potential anti-inflammatory agents.

Key words : anti-oxidant, iNOS, COX-2, cytokine, Allium sativum

\section{서 론}

*Corresponding author. E-mail : anbj@dhu.ac.kr Phone : 82-53-819-1435, Fax : 82-53-819-1435

Received 12 March 2015; Revised 1 June 2015; Accepted 15 July 2015.

Copyright (c) The Korean Society of Food Preservation. All rights reserved.
산화적 스트레스에 의해 발생되는 활성산소종(reactive oxygen species, ROS)은 과다한 염증반응(1) 및 세포 손상, 노화(2)에 관계하여 질병을 야기한다. 이러한 $\mathrm{ROS}$ 는 vitamin $\mathrm{A}$, vitamin $\mathrm{C}$, vitamin $\mathrm{E}$, glutathion 등 항산화 물질에 의해 줄이거나 예방 할 수 있다(1,3-5). 염증반응은 외부자 극에 대응하기 위해서 생체에서 일어나는 정상적인 방어 기작인데(6), 염증반응이 일어나면 nitric oxide(NO), tumor necrosis factor- $a(\mathrm{TNF}-a)$, interleukin-1 $(\mathrm{IL}-1 \beta)(7)$, interleukin-6 
(IL-6), prostaglandin $\mathrm{E}_{2}\left(\mathrm{PGE}_{2}\right)(8)$ 가 inducible nitric oxide synthase(iNOS)와 cyclooxygenase-2(COX-2)에 의해 생성된 다(9). 산화적 스트레스에 의해 발생되는 노화 및 염증이 야기하는 질병에 대응하기 위한 연구가 활발히 이루어 지 고 있다 $(10,11)$.

마늘(Allium sativum L.)은 백합과(Lilliaceae) 파속 (Allium)에 속하는 인경작물로서(12) 중앙아시아와 지중해 연안 지방으로 전해지고 있으며 우리나라를 비롯한 중국, 인도, 미국 및 남부유럽등지에서 광범위하게 재배되고 있 다(13). 식재료로 인기가 많으며 마늘 추출물은 고콜레스테 롤증, 당뇨병, 혈전증과같은 심혈관계 질병 치료에 효과가 있다고 알려져 있다. 또한 항균, 항산화, 항발암성의 효과를 지니고 있다(14). 마늘의 성장을 위해서는 5월 초순경부터 마늘대를 뽑아주어야 하는데 이시기에 제거하지 않게 되면 구근의 성장이 이루어지지 않고 잎줄기도 질기어져 식용할 수 없게 된다. 마늘 재배 농가의 부산물인 마늘대는 수확초 기에 절임 등으로 일부 이용되나, 그 대부분은 마늘밭에 그대로 폐기 처분되고 있는 실정으로 마늘의 재배량이 증가 됨에 따라 그 부산물인 마늘대의 폐기량은 늘어나게 되지만 이에 대한 대책이나 이용방안을 제시하기 위해 수행된 연구 는 마늘대를 첨가한 식빵의 제조(15) 정도뿐 거의 없는 실정 이다.

본 연구에서는 폐자원으로 인식되는 마늘대를 활용하기 위해 열수, $70 \%$ 에탄올로 추출하여 항산화 효과를 측정하 고 lipopolysaccharide로 유도된 대식세포를 이용하여 염증 성 사이토카인 및 iNOS, COX-2 발현에 미치는 영향을 연구 하고자 하였다. 용매추출물별 효능을 확인하여 농산 부산 물인 마늘대의 활용가치를 올리고 기능성 소재로서의 발굴 을 위한 기본적인 자료로 사용될 수 있을 것으로 기대된다.

\section{재료 및 방법}

\section{재료 및 시료 추출}

본 실험에 사용한 마늘대는 국내산을 구입하여 재료로 사용하였다. 열수추출물(ASSW)의 용매는 시료 중량의 10 배 양을 가하여 $85^{\circ} \mathrm{C}$ 에서 4시간씩 3회 반복 추출하였고, $70 \%$ 에탄올 추출물(ASSE)은 시료 중량의 10 배의 용매를 가하여 실온에서 24 시간 침지하여 상등액과 침전물을 분리 하여 동일한 방법으로 3 회 반복 추출하였다. 각 추출물들은 여과 및 농축 후 동결 건조하여 냉장실에 보관하면서 본 실험의 시료로 사용하였다.

\section{총 폴리페놀 화합물 함량 측정}

총 페놀 화합물은 Folin-Denis 방법(16)으로 측정하였으 며, 시료를 $10 \mathrm{mg} / \mathrm{mL}$ 농도로 증류수에 녹인 다음 $0.2 \mathrm{~mL}$ Folin Ciocalteu reagent를 첨가하여 잘 혼합한 후 3 분간 실온
에 방치하였다. 3 분 후 $\mathrm{Na}_{2} \mathrm{CO}_{3}$ 포화용액 $0.4 \mathrm{~mL}$ 를 가하여 혼합하고 증류수를 첨가하여 $4 \mathrm{~mL}$ 로 만든 후 실온에서 1시간 방치하고, $725 \mathrm{~nm}$ 에서 흡광도를 측정하였다. 이때 총 폴리페놀 화합물은 tannic acid를 이용한 표준곡선으로 부터 양을 환산하였다.

\section{전자공여능 확인}

전자공여능(EDA: electron donating abilities)은 $\mathrm{DPPH}$ 를 ethanol에 녹여 용액을 준비하고, ASSW와 ASSE를 각각 $5,10,50,100,500,1000 \mu \mathrm{g} / \mathrm{mL}$ 의 농도로 제조하여 각 농도 별 시료 $120 \mu \mathrm{L}$ 에 DPPH $60 \mu \mathrm{L}$ 를 첨가한 후 96 well plate에 혼합하여 실온에서 빛을 차단하고 30 분간 반응시킨 후 ELISA reader(Spectra max 190, Molecular devices, Sunnyvale, ,CA, USA)를 사용하여 $517 \mathrm{~nm}$ 에서 흡광도를 측정하여 $\mathrm{DPPH}$ 의 free radical 소거활성을 측정하였다. Positive control로는 L-ascorbic acid를 사용하였다.

\section{$\mathrm{ABTS}^{+}$cation radical scavenging activity 확인}

$7 \mathrm{mM} \mathrm{ABTS}$ 수용액과 $2.45 \mathrm{mM}$ potassium persulfate를 같은 양으로 혼합하고 암실에서 24시간동안 방치하여 반응 시킴으로써 $\mathrm{ABTS}^{+}$이온을 형성시킨다. 형성된 $\mathrm{ABTS}^{+}$이 온 용액을 용매로 희석시킨후 희석된 $\mathrm{ABTS}^{+}$용액 $100 \mu \mathrm{L}$ 과 추출물 $100 \mu \mathrm{L}$ 를 가하여 실온에서 7 분간 반응시킨 다음 파장 $734 \mathrm{~nm}$ 에서 흡광도를 측정하여 radical 소거능(\%)으 로 나타내었다. Positive control로는 L-ascorbic acid를 사용 하였다.

\section{세포 배양}

본 실험에 이용한 Raw 264.7 세포의 배양은 $10 \%$ FBS과 $1 \%$ penicillin/streptomycin $(100 \mathrm{U} / \mathrm{mL})$ 을 첨가한 DMEM 배 지를 사용하였으며, $37^{\circ} \mathrm{C}, 5 \% \mathrm{CO}_{2}$ incubator(VS-9160GC, Hanbaek Scientific Co., Daejeon, Korea)에 적응시켜 계대 배양하였다.

\section{MTT assay에 의한 세포 독성 확인}

세포 독성 측정은 Carmichael(17)의 방법에 따라 측정하 였다. Raw 264.7 cells 은 96 well plate에 $5 \times 10^{4}$ cells/well이 되게 $0.18 \mathrm{~mL}$ 분주하고, 시료를 농도 별로 조제하여 0.02 $\mathrm{mL}$ 첨가한 후 $37^{\circ} \mathrm{C}, 5 \% \mathrm{CO}_{2}$ incubator에서 24 시간 배양하 였다. 마늘대 $10,25,50,100,250,400 \mu \mathrm{g} / \mathrm{mL}$ 농도별로 24 시간 동안 처리하였다. 여기에 $2.5 \mathrm{mg} / \mathrm{mL}$ 농도로 제조한 MTT 용액 $0.02 \mathrm{~mL}$ 첨가하여 4시간 배양한 후 배양액을 제거하고 각 well당 DMSO $0.1 \mathrm{~mL}$ 를 가하여 실온에서 30 분 간 반응 시킨 뒤 ELISA reader로 $540 \mathrm{~nm}$ 에서 흡광도를 측정하였다. 세포 독성 측정은 시료용액의 첨가군와 무첨 가군의 흡광도 감소율로 나타내었다. 


\section{Nitric oxide 저해활성 측정}

Nitric oxide(NO) 측정은 cell의 supernatant에서의 nitric oxide의 양을 nitrite and nitrate로서 측정을 하였다(18). Nitrite에 대한 nitrate로 환원된 후의 안전한 형태인 griess reagent(Sigma Chemical Co., Ltd., St. Louis, Missouri, USA) 를 사용하였으며, 6 well plate에 $2 \times 10^{6}$ 개의 cell을 confluence가 $80 \%$ 일 때, $1 \times \mathrm{PBS}$ 로 2 번 washing한 후 무혈청 배지를 사용하여 12 시간 이상 배양시킨 다음 LPS (lipopolysacchride) $10 \mathrm{\mu g} / \mathrm{mL}$ 을 control 군을 뺀 모든 well에 다 넣어서 자극시켰다. 2 시간 후에 시료를 농도별로 처리하 여 실험하였다. NO 생성량은 24시간 후에 supernatant를 모아 griess regent로 10 분간 반응시킨 후에 $540 \mathrm{~nm}$ 에서 흡 광도로 측정하였다.

\section{Pro-inflammatory cytokine 분비량 측정}

Raw 264.7 세포를 $2 \times 10^{5}$ cells $/ \mathrm{mL}$ 로 조절한 후 6 well plate에 접종하고 24시간 동안 전 배양하였다. 세포에 $1 \mu$ $\mathrm{g} / \mathrm{mL}$ 의 LPS와 추출물을 동시에 처리하여 24시간 재 배양 하였다. 세포배양액 내의 IL-6, TNF- $a$, IL-1 $\beta$, PGE2 cytokine의 분비량을 ELISA kit(Mouse ELISA set, R\&D Systems, Minneapolis, MN 55413, USA)를 이용하여 측정하 였다.

Western blot을 통한 iNOS, COX-2 단백질 발현 측정 세포를 $1 \mathrm{X}$ PBS로 2회 세척 후 RIPA buffer $10 \mathrm{~mL}$ 에 complate mini $1 \mathrm{tab}$ 를 가하여 $70 \mu \mathrm{L}$ 로 용해해서 centrifuge (CVS-15000CFNII, Vision, Daejeon, Korea)를 이용하여 $4^{\circ} \mathrm{C}$ $12,000 \mathrm{rpm}$ 에서 15 분간 원심 분리 하였다. 원심 분리하여 얻은 상층액은 Bradford assay로 정량하여 $20 \mu \mathrm{L}$ 의 단백질 을 $10 \%$ 의 SDS-PAGE에서 전기 영동하여 분리하였다. 분리 된 단백질은 power supply electrophoresis(Powerpac ${ }^{\mathrm{TM}} \mathrm{HC}$, BIO RAD, California, USA)를 이용하여 PVDF membrane에 옮긴 다음 실온에서 30 분 동안 blocking buffer $5 \%$ skim milk in TBST)에서 incubation 시켰다. 1차 항체(iNOS, $\mathrm{COX}-2$ )를 희석하여 2 시간 동안 반응한 다음, 다시 10 분 간격으로 TBST로 3회 washing 하고 membrane을 HRP가 중합된 각각의 2 차 항체를 $1: 1,000$ 로 희석하여 60 분 동안 반응시켰다. 3회 washing 한 뒤 Western Imaging system (CAS-400SM, Davinch-K, Seoul, Korea) 기기를 이용하여 iNOS, COX-2 밴드 확인 및 정량을 실시하였다.

\section{통계처리}

모든 실험은 3회 반복하여 측정하였고, 그 결과는 평균값 \pm 표준편차로 나타냈으며 통계적 분석은 SPSS 프로그램을 이용하여 각 처리구간의 유의성 $\left.{ }^{* *} \mathrm{p}<0.05,{ }^{*} \mathrm{p}<0.01\right)$ 검증을 위해 분산분석(analysis of variance, ANOVA) 후 Turkey test 로 다중비교를 실시하였다.

\section{결과 및 고찰}

\section{총 폴리페놀 함량}

Phenol성 화합물은 phenolic hydroxyl기를 갖기 때문에 단백질 및 기타 거대 분자들과 쉽게 결합하여 항산화, 항암, 항염증 및 항알레르기 작용 등의 다양한 생리활성을 나타내 는 것으로 알려져 있다. 또한 이런 phenol성 화합물들은 염증 반응에 관여하는 enzyme activity뿐만 아니라 enzyme expression을 조절하여 항염증 활성을 나타낸다 $(19,20)$. 일 상적으로 섭취하고 있는 식용식물에서 천연 항산화제를 탐색하는 연구가 활발히 진행되고 있으며, 현재 알려진 천 연 항산화 영양성분으로는 $\beta$-carotene 비타민 $\mathrm{E}$, 비타민 C 등의 비타민과 같은 미량무기질 및 페놀계 화합물들로 이들 의 항암효과 또한 항산화 능력에 기인한다고 보고되고 있다 $(21,22)$. Tannic acid를 지표물질로 하여 작성한 표준곡선에 의해 마늘대의 폴리페놀 함량을 측정하여 Table 1 와 같이 나타내었다. 마늘대 열수추출물(ASSW)은 $37.08 \mathrm{mg} / \mathrm{g}, 70 \%$ 에탄올 추출물(ASSE)은 $44.7 \mathrm{mg} / \mathrm{g}$ 으로 열수추출물보다 에탄올추출물에서 폴리페놀 함량이 더 높은 것으로 나타났 다. 약용식물 추출물의 폴리페놀 함량 분석(23)에서 나온 갈근 $(5.50 \mathrm{mg} / \mathrm{g})$, 갈화 $(6.46 \mathrm{mg} / \mathrm{g})$, 감국 $(2.48 \mathrm{mg} / \mathrm{g})$ 등을 비 교하였을 때 $\mathrm{ASSW}, \mathrm{ASSE}$ 의 폴리페놀 함량이 매우 높은 것을 확인 할 수 있었다.

Table 1. The contents of total polyphenols of solvent fractions from Allium sativum L. stems

\begin{tabular}{cc}
\hline Samples & $\begin{array}{c}\text { Total phenolics } \\
\left(\mathrm{mg} \mathrm{TAE}^{1} \mathrm{~g}^{1}\right)\end{array}$ \\
\hline Distilled water ext. & $37.08 \pm 1.51$ \\
$70 \%$ EtOH ext. & $44.7 \pm 1.32$ \\
\hline
\end{tabular}

${ }^{11}$ The total phenolic contents was expressed as milligram of the tannic acid equivalent (TAE) per gram of extract.

\section{항산화능}

항산화 효과에 널리 사용되는 1,1-diphenyl-2-picrylhydrazyl $(\mathrm{DPPH})$ 는 분자 중에 있는 여분의 전자를 공유함으로서 안 정한 자유라디칼의 성질을 가지고 있고, DPPH 용액이 다른 물질과 혼합되면 환원이 많이 될수록 보라색을 잃게되는 형상을 나타낸다(24). $517 \mathrm{~nm}$ 의 흡광도에서 자유라디칼 소 거 활성능력을 통하여 남아있는DPPH의 비율로 항산화의 기능을 측정할 수 있다(25). 마늘대의 DPPH 라디칼 소거 활성능력을 측정한 결과 Fig. 1와 같이 나타내었다. ASSW, ASSE 모두에서 농도 의존적으로 증가하였으며 $1,000 \mu$ $\mathrm{g} / \mathrm{mL}$ 에서 $\mathrm{ASSW}$ 의 경우 $44 \%, \mathrm{ASSE}$ 의 경우 $50.83 \%$ 를 나타 냈다. 기능성 소재로 사용시 ASSW보다 ASSE에서 약간 더 높은 항산화 효과도 기대할 수 있을 것으로 보인다.

ABTS[Diammonium 2,2'-azino-bis(3-ethylbenzothiazoline6-sulfonate)] 라디칼 이온은 추출물의 항산화 활성을 측정 
하는데 사용되는 파장대를 이용하여 측정하는 실험중 하나 로 사용되어오고 있다(26-28). 마늘대 열수추출물 및 70\% 에탄올 추출물의 $\mathrm{ABTS}^{+}$전자공여능은 Fig. 2 와 같이 나타 내었다. 모든 추출물에서 농도 의존적으로 활성이 증가하 였으며 $1,000 \mu \mathrm{g} / \mathrm{mL}$ 에서 $\mathrm{ASSW}$ 의 경우 $96.85 \%, \mathrm{ASSE}$ 의 경우 $97.79 \%$ 를 나타내었다. 대조군인 Vitamin C의 경우 $50 \mu \mathrm{g} / \mathrm{mL}$ 의 농도에서 $97.94 \%$ 의 소거능을 나타내었으며, ASSW, ASSE가 $1,000 \mu \mathrm{g} / \mathrm{mL}$ 에서 Vit.C의 농도가 $50 \mathrm{mg} / \mathrm{mL}$ 일 때의 소거능과 비슷한 항산화력을 나타낸다는 것을 확인 하였다.

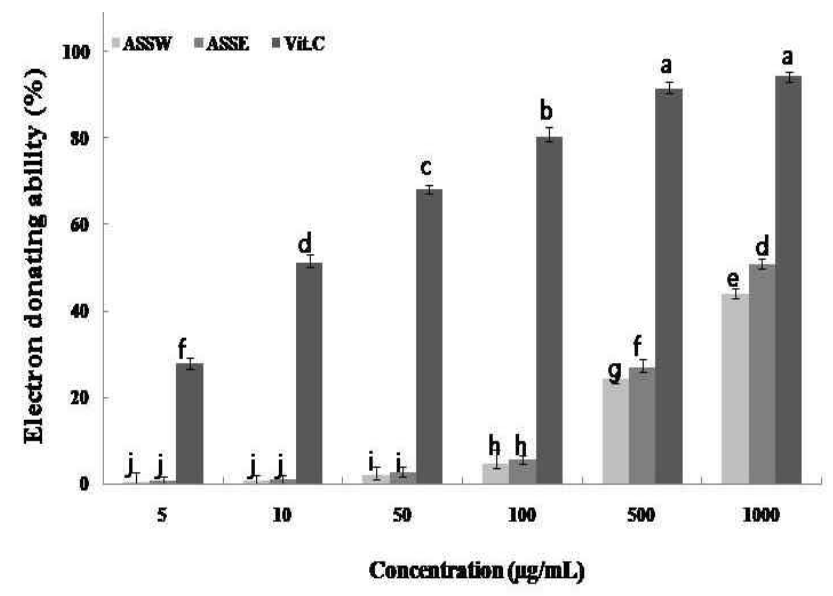

Fig. 1. Electron donating ability of Allium sativum L. Stems extracted with distilled water and $70 \%$ ethanol.

ASSW, extracted with water; ASSE, extracted with 70\% ethanol.

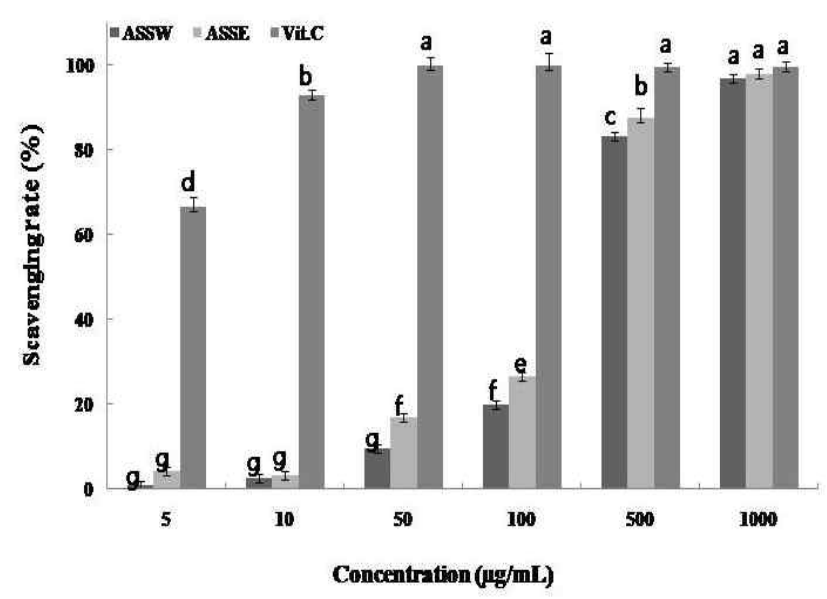

Fig. 2. $\mathrm{ABTS}^{+}$cation radical scavenging activity of extracted from Allium sativum L.

ASSW, extracted with water; ASSE, extracted with 70\% ethanol.

\section{Macrophage cell(Raw 264.7)에 대한 세포독성}

MTT assay 시험법을 통해 macrophage cells 에 대한 마늘 대 추출물의 농도조건 별 세포독성을 확인하였다(Fig. 3). 마늘대 열수추출물과 에탄올추출물 모두 $250 \mu \mathrm{g} / \mathrm{mL}$ 이상 시료농도 조건에서 세포독성을 나타내는 것을 확인하였으
며, 각 추출물의 항염증 효능에 대한 상대적 비교를 위하여 세포독성을 나타내지 않은 $100 \mathrm{\mu g} / \mathrm{mL}$ 농도를 시험시료 농 도조건으로 설정하였다.

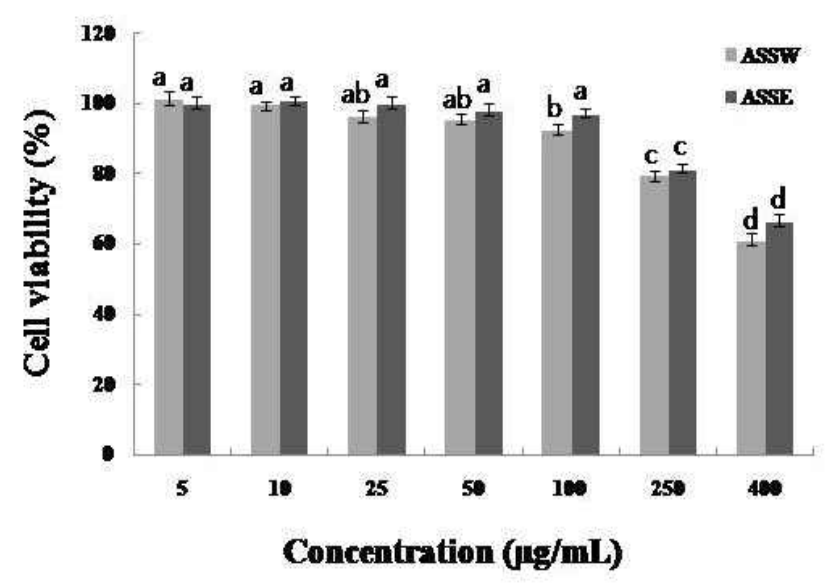

Fig. 3. Cell viability of ASSW, ASSE on Raw 264.7 cell.

Raw 264.7 cells were treated with 5, 10,25, 50,100, 250, $400 \mu \mathrm{g} / \mathrm{mL}$ of ASSW, ASSE dissolved in media for $1 \mathrm{hr}$ prior to the addition of LPS $(1 \mu \mathrm{g} / \mathrm{mL})$, and the cells were further incubated for $24 \mathrm{hr}$. Data represent the mean \pm SD with eight separate experiments.

\section{Nitric oxide 저해 효과}

Inducible nitric oxide synthase(iNOS)에 의해 L-arginine으 로부터 생성되는 무기 유리체로 정상적인 상태 에서는 신경 전달, 혈관 확장, 면역 반응 등의 생리적인 기능을 조절하는 중요한 역할을 하지만(29,30), 염증 반응에서 과발현된 NO 는 혈관 투과성을 증가시켜 부종을 일으키고 염증을 심화시 켜 다양한 세포 및 조직손상을 일으켜 만성 염증 질환 및 자가면역질환 등을 초래하는 것으로 알려져 있다(31). LPS 로 유도된 Raw 264.7 Cells에 마늘대추출물 농도별 $(5,10$, $25,50,100 \mu \mathrm{g} / \mathrm{mL}$ )로 처리하여 상등액속에 있는 $\mathrm{NO}$ 의 양을 측정하였고, $25 \mu \mathrm{g} / \mathrm{mL}$ 부터 $\mathrm{NO}$ 생성량이 유의적으로 줄어 $100 \mu \mathrm{g} / \mathrm{mL}$ 에서 ASSW는 약 $18 \% \mathrm{ASSE}$ 의 경우는 약 $23 \%$ 의 저해효과를 나타냈다. ASSW보다 ASSE에서 NO 생성 억제 효과가 조금더 우수함을 확인함으로써 ASSE에서 iNOS 효소억제능이 ASSW보다 높을 것으로 사료된다(Fig. 4).

IL-6, IL-1 $\beta, T N F-a, P G E 2$ 사이토카인 생성 억제 효과 산화적 스트레스로 인하여 인체에 나타나는 피부 관련 질환의 대다수가 염증을 동반하는데, 이로 인해 노화가 촉 진되며, 피부 질환이 더욱 악화되고, IL- $1 \beta, \mathrm{TNF}-\alpha, \mathrm{IL}-6$ 와 같은 염증성 사이토카인이 생성된다(32,33). $\mathrm{PGE}_{2}$ 또한 $\mathrm{NO}$ 와 마찬가지로 손상된 부위나 조직에서 통증과 발열의 전달 에 주로 관여하는 중요한 염증매개물질로서 COX-2에 의해 합성되는데 과량 생산되면 과도한 면역만응을 야기하여 다발성경화증, 파킨슨병, 알츠하이머병, 대장암과 같은 각 종 염증성 질환을 유발시키게 된다(34). IL-6는 대표적인 염증성 사이토카인으로서 다양한 요인에 의해 합성되어 
분비되면서 급성 혹은 만성 염증질환의 발생 및 진행 과정 에서 중요한 역할을 하며(35,36), TNF- $a$ 는 염증 반응 초기 에 해당 부위로 호중구를 유도하며, 급성 염증 반응을 일으 키고 악화 시키는 인자이고(37), IL-1ß는 대식세포를 활성 화시키고, 림프구 및 호중구의 내피세포 접착을 항진시키 며, 케모카인의 생성을 유도하여 염증 부위에 염증세포의 침윤을 상승시킨다(38). 본 연구에서 $\mathrm{ASSW}, \mathrm{ASSE}$ 는 염증

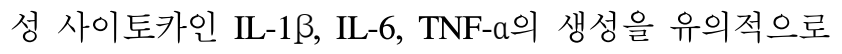
감소시켰으며, 각각 $\mathrm{IL}-1 \beta$ 는 $100 \mu \mathrm{g} / \mathrm{mL}$ 의 농도에서, $\mathrm{IL}-6$ 는 $100 \mu \mathrm{g} / \mathrm{mL}$ 의 농도에서, TNF-a 는 $100 \mu \mathrm{g} / \mathrm{mL}$ 의 농도에서 유의한 감소를 나타냈다. $\mathrm{PGE}_{2}$ 는 $\mathrm{ASSW} 100 \mu \mathrm{g} / \mathrm{mL}$ 의 농도 구간에서 발현량이 현저하게 감소하였으며, $\mathrm{ASSE}$ 는 농도 의존적으로 발현량이 감소되어 $100 \mu \mathrm{g} / \mathrm{mL}$ 에서 $33.87 \%$ 의 저해율을 나타내었다(Fig. 5). 결과적으로 ASSE가 ASSW 보다 염증 관련 사이토카인의 생성 억제가 높다는 것을 알 수 있었으며, 다른 염증 세포들의 이주를 비롯하여 활성 과 분화도 감소시킬 수 있음을 추정할 수 있었다.

\section{iNOS 및 COX-2 단밸질 발현 억제 효과}

$\mathrm{iNOS}$ 의 발현은 세포내 $\mathrm{Ca}^{2+}$ 농도와 관계없이 세균성 독 소 또는 염증 및 면역반응, 허혈, 조직손상, 산화성 스트레스 등에 따라 유리되는 여러 종류의 cytokine(IL-1 $\beta$, TNF-a 등)에 의해서 유전자 전사단계에서 유도되며, 이에 따라 $\mathrm{NO}$ 가 대량 생성 유리될 경우에는 질병의 병태생리에 중요 한 인자로 관여할 수 있다(39). COX-2는 염증 반응뿐만 아니라 혈액응고, 신장기능, 혈관조절 및 면역 반응 등에 관여하고, 염증성 cytokine이 분비되면 $\mathrm{COX}-2$ 가 활성화 된 다(40). 또한 COX-2는 염증조직, 악성 종양조직에서 정상 세포에 비해 많은 양의 프로스타글란딘의 생성을 유도하여 혈관 생성을 촉진하고 세포의 증식을 도울 뿐 아니라 면역

[A]

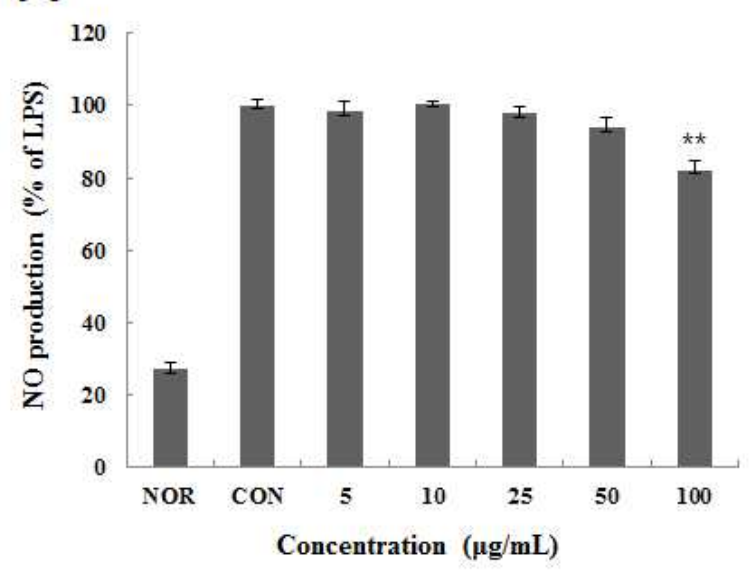

능력을 억제함으로써 암세포 성장에 좋은 환경을 제공하여 $\mathrm{COX}-2$ 의 발현은 또 다른 질병의 병원성과 직접적인 연관 성을 시사하고 있다(41). ASSW, ASSE의 iNOS, COX-2 protein 발현에 대한 효과를 알아보기 위해 western blot을 수행하였다. 그 결과, LPS 처리에 의해 증가된 열수 추출물 의 iNOS, COX-2 발현은 $100 \mu \mathrm{g} / \mathrm{mL}$ 의 농도구간 까지 일정 하게 나타냈으며(Fig. 6), $70 \% \mathrm{EtOH}$ 의 추출물에서 $\mathrm{iNOS}$ 의 발현은 $100 \mathrm{\mu g} / \mathrm{mL}$ 농도구간에서 현저하게 억제됨을 확인 하였고, $\mathrm{COX}-2$ 의 발현은 농도 의존적으로 저하되어 특히 $50 \mu \mathrm{g} / \mathrm{mL}, 100 \mu \mathrm{g} / \mathrm{mL}$ 의 농도에서 현저하게 억제되는 것을 확인하였다(Fig. 7).

\section{요 약}

본 연구에서는 마늘의 부산물로 발생하는 마늘대의 항산 화 및 항염증 효과를 알아보기 위하여 LPS로 염증을 유도한 Raw 264.7 세포에 대한 열수추출물(ASSW)과 $70 \%$ 에탄올 추출물(ASSE)의 효과를 살펴보았다. ASSW의 폴리페놀 함 량은 $37.08 \pm 1.51 \mathrm{mg}(\mathrm{TAE}) / \mathrm{g}, \mathrm{ASSE}$ 의 폴리페놀 함량은 $44.7 \pm 1.32 \mathrm{mg}(\mathrm{TAE}) / \mathrm{g}$ 이 함유되어있음을 확인하였다. $\mathrm{DPPH}$ 실험과 $\mathrm{ABTS}^{+}$실험에서 $\mathrm{ASSW}, \mathrm{ASSE}$ 모두 농도 의존적으로 증가하였으며, $\mathrm{DPPH}$ 의 경우 $1,000 \mathrm{\mu g} / \mathrm{mL}$ 에서 대조군인 Vit.C의 $50 \mathrm{\mu g} / \mathrm{mL}$ 의 항산화능이 있다는 것이 확 인되었고, $\mathrm{ABTS}^{+}$의 경우 $500 \mathrm{\mu g} / \mathrm{mL}$ 이상부터 대조군인 Vit.C와 비슷한 효과를 나타냄으로서 ASSW, ASSE 모두 항산화능이 있다는 것을 확인하였다. MTT측정으로 인해 세포 독성을 가지지 않았던 농도대 $(5,10,25,50,100 \mathrm{\mu g} / \mathrm{mL})$ 에서 염증 억제 효과를 살펴보기 위해 $\mathrm{NO}$ 를 측정한 결과 $\mathrm{ASSW}, \mathrm{ASSE}$ 모두 $25 \mu \mathrm{g} / \mathrm{mL}$ 에서부터 유의적으로 분비량

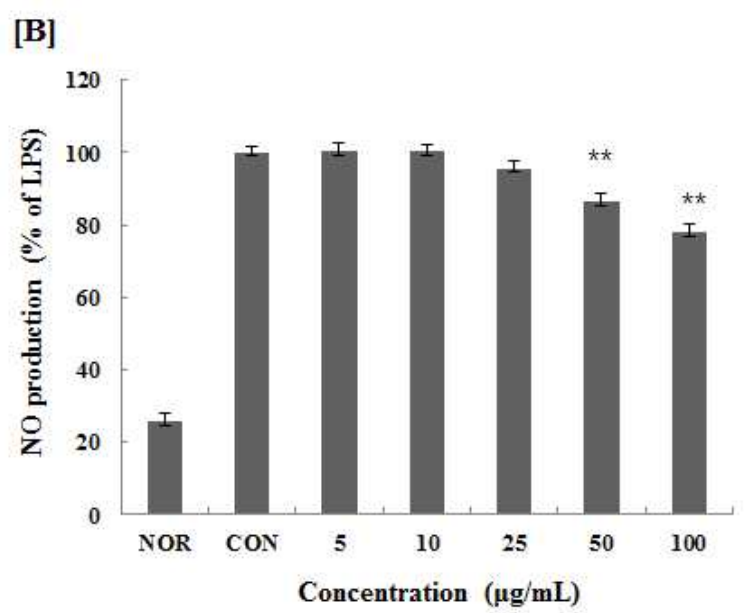

Fig. 4. Inhibitory effects of ASSW, ASSE on the production of nitric oxide Raw 264.7 cells.

Raw 264.7 cells were cultured with LPS $(1 \mu \mathrm{g} / \mathrm{mL})$ in the presence or absence of ASSW, ASSE for $24 \mathrm{hr}$ to determine the level of NO. Nor : LPS not induced group, Con : LPS induced group. [A] ASSW : extracted with water. [B] ASSE : extracted with $70 \%$ ethanol. The data represent the mean \pm SD of three separate experiments (significant as compared to control. ${ }^{\star \star} \mathrm{p}<0.05,{ }^{\star} \mathrm{p}<0.01$ ). 
[A]

(a)

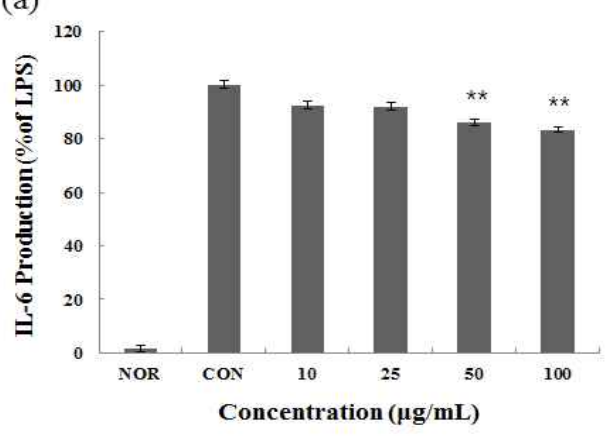

[B]

(a)

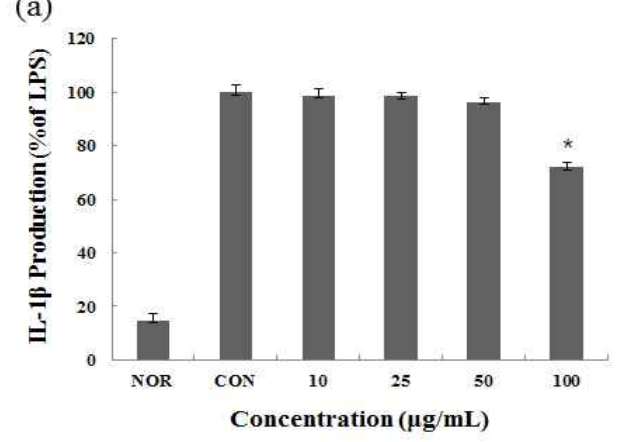

[C]

(a)

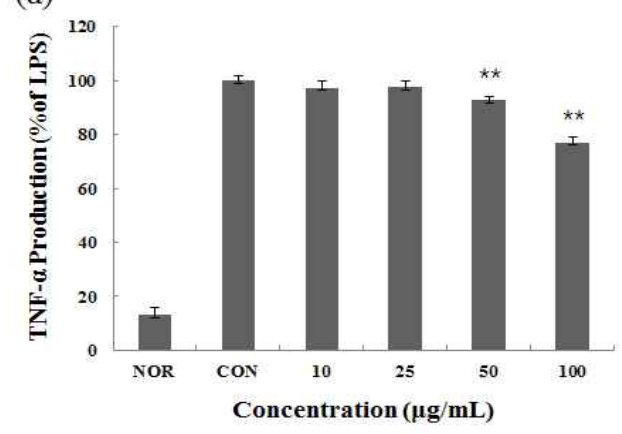

[D]

(a)

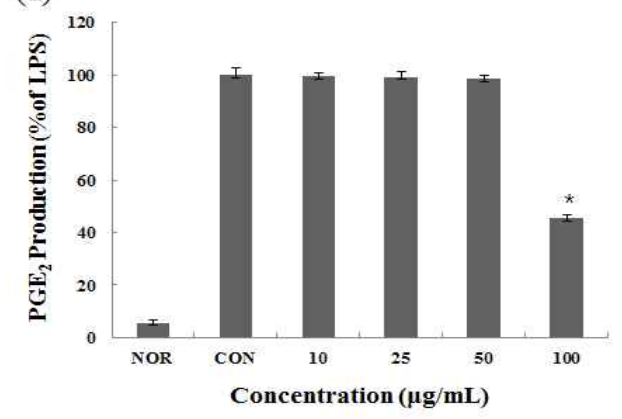

(b)

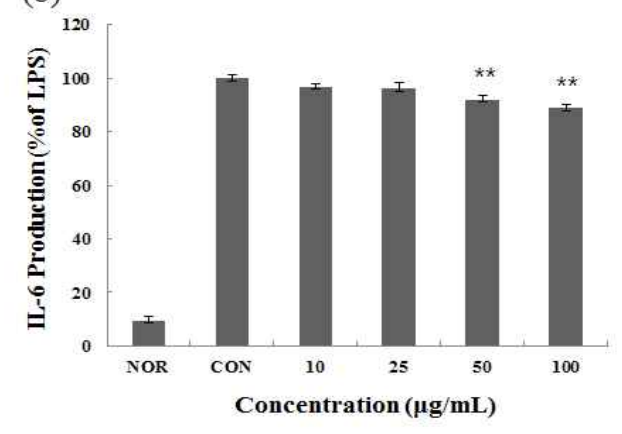

(b)

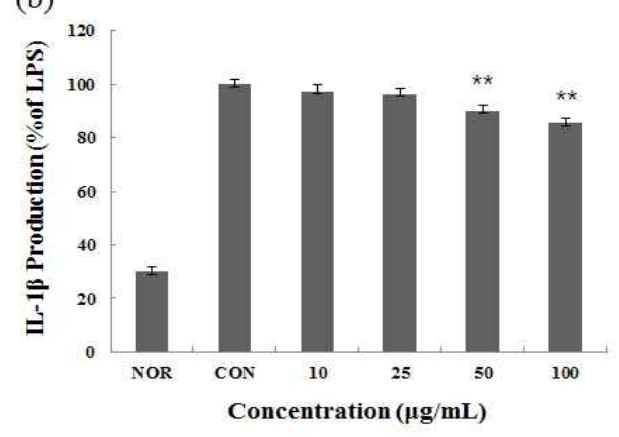

(b)

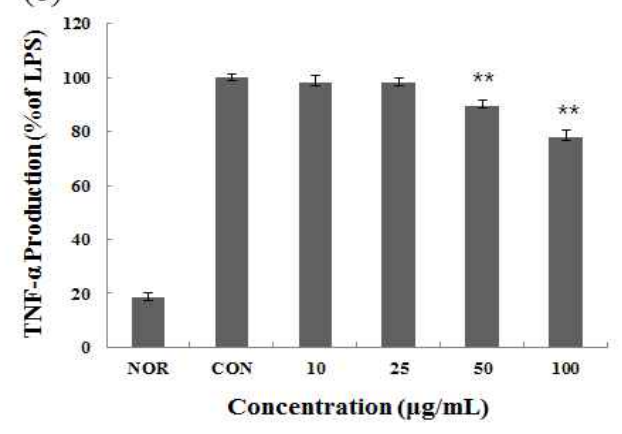

(b)

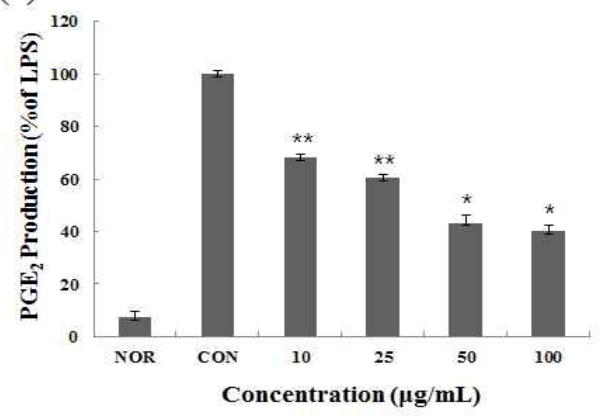

Fig. 5. Effect of ASSW, ASSE on the production of cytokines stimulated by LPS.

Production of [A] IL-6, [B] IL-1 $\beta$, [C] TNF-a, [D] PGE 2 were measured in the medium of Raw 264.7 cells cultured with LPS (1 $\mu \mathrm{g} / \mathrm{mL})$ in the presence or absence of ASSW, ASSE for $24 \mathrm{hr}$. The amount of IL-6, IL-1 $\beta$, TNF- $a$, PGE 2 was measured by immunoassay as described in materials and methods. Nor : LPS not induced group, Con : LPS induced group. (a) ASSW : extracted with water. (b) ASSE : extracted with 70\% ethanol. Data represent the mean \pm SD with three separate experiments. (significant as compared to control. ${ }^{* *} \mathrm{p}<0.05,{ }^{*} \mathrm{p}<0.01$ ). 

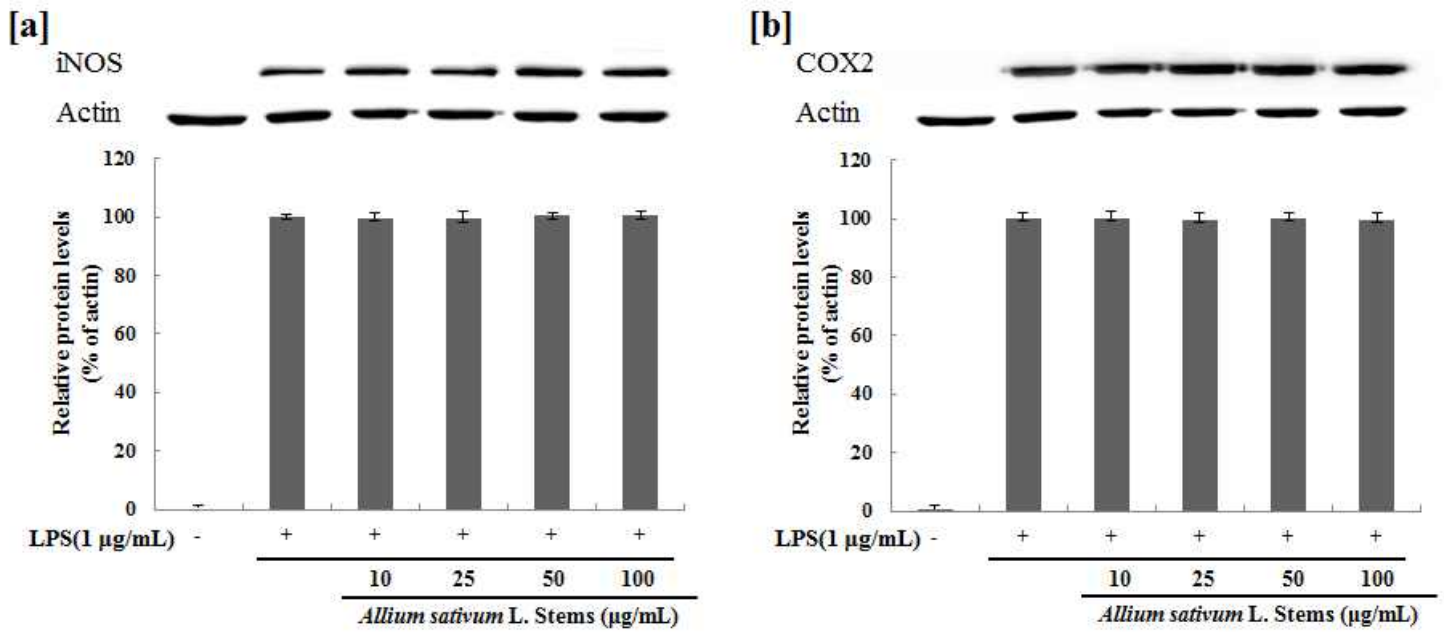

Fig. 6. Inhibitory effects of ASSW on the protein levels of iNOS and COX-2 Raw 264.7 cells.

Raw 264.7 cells $\left(5 \times 10^{4}\right.$ cells/well) were pre-incubated for $24 \mathrm{hr}$, and the cells were stimulated with lipopolysaccharide $(1 \mathrm{\mu g} / \mathrm{mL})$ in the presence of complex extracts sample $(10,25,50,100 \mu \mathrm{g} / \mathrm{mL})$ for $24 \mathrm{hr}$. Nor : LPS not induced group, Con : LPS induced group. The data represent the mean \pm SD of three separate experiments (significant as compared to control. $\left.{ }^{* *} \mathrm{p}<0.05,{ }^{*} \mathrm{p}<0.01\right)$.

[a]

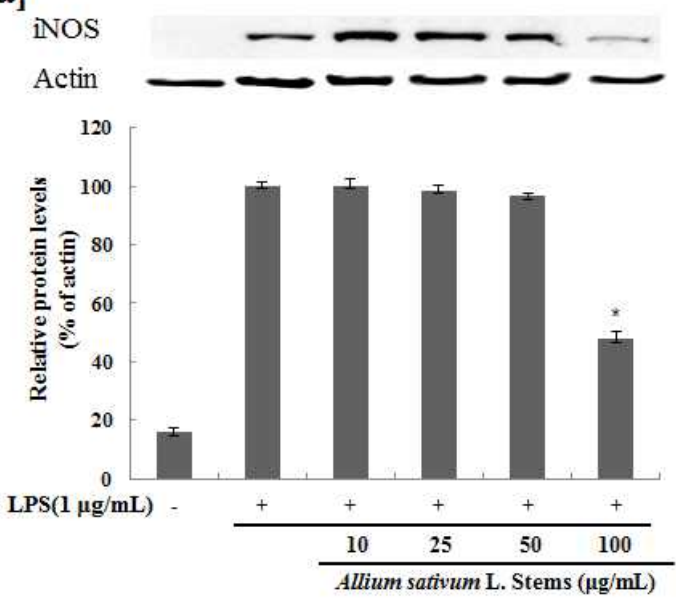

[b]

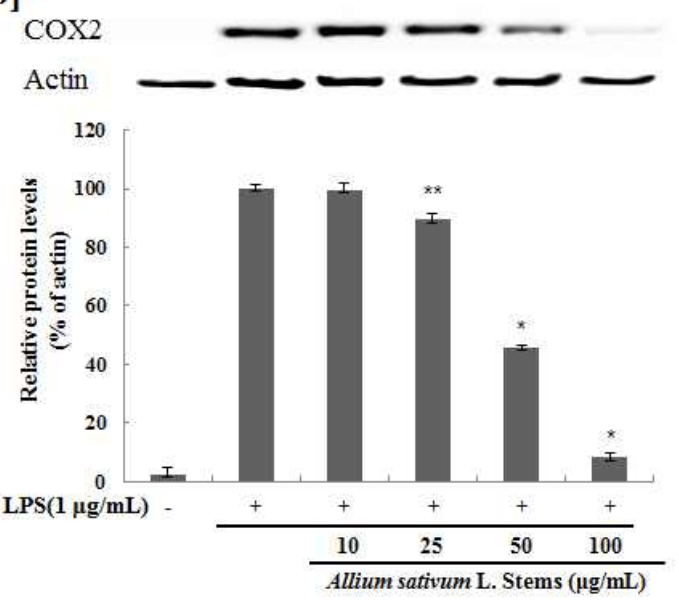

Fig. 7. Inhibitory effects of ASSE on the protein levels of iNOS and COX-2 Raw 264.7 cells.

Raw 264.7 cells $\left(5 \times 10^{4}\right.$ cells/well) were pre-incubated for $24 \mathrm{hr}$, and the cells were stimulated with lipopolysaccharide $(1 \mathrm{\mu g} / \mathrm{mL})$ in the presence of complex extracts sample $(10,25,50,100 \mu \mathrm{g} / \mathrm{mL})$ for $24 \mathrm{hr}$. Nor : LPS not induced group, Con : LPS induced group. The data represent the mean \pm SD of three separate experiments (significant as compared to control. ${ }^{* *} \mathrm{p}<0.05,{ }^{*} \mathrm{p}<0.01$ ).

이 감소함을 확인하였으며 특히 $100 \mathrm{\mu g} / \mathrm{mL}$ 의 농도에서 약 $18 \%, 23 \%$ 의 억제 효과를 보였다. 또한 대식세포의 염증성 cytokine인 IL-6, TNF- $a, \mathrm{IL}-1 \beta$ 및 $\mathrm{PGE}_{2}$ 의 분비량을 첨가 농도 의존적으로 억제함을 확인하였다. 특히 $\mathrm{PGE}_{2}$ 에 대해 ASSW, ASSE $100 \mathrm{\mu g} / \mathrm{mL}$ 의 농도에서 약 $55 \%, 60 \%$ 의 감소 효과를 보였다. ASSW의 iNOS, COX-2의 발현 저해효과는 나타내지 못하였지만, ASSE는 $100 \mu \mathrm{g} / \mathrm{mL}$ 의 농도에서 $\mathrm{iNOS}$ 의 발현량이 현저하게 억제됨을 확인하였고, $\mathrm{COX}-2$ 의 경우 농도 의존적으로 저하되어 특히 $50 \mathrm{\mu g} / \mathrm{mL}, 100$ $\mathrm{\mu g} / \mathrm{mL}$ 의 구간에서 단백질 발현 저해효과가 있음을 확인하 였다. 이를 통해 ASSW, ASSE 모두 항산화 효과와 항염증
효과가 있음을 확인하였으며, ASSW 보다 ASSE에서 활성 산소종(reactive oxygen species, ROS) 및 ROS에 의해 유발 되는 염증을 억제시켜주는 소재가 될수있을 것이라 예상 된다.

\section{감사의 글}

본 연구는 산업통상자원부의 지역특화산업 육성 기술개 발 사업(과제번호: R0002964)의 지원에 의해 수행되었으며 이에 감사드립니다. 


\section{References}

1. Haddad JJ (2002) Antioxidant and prooxidant mechanisms in the regulation of redox (y)-sensitive transcription factor. Cell Signal, 14, 879-897

2. Beckman KB, Ames BN (1998) The free radical theory of aging matures. Physiol Rev, 78, 547-581

3. Balaban RS, Nemoto S, Finkel T (2005) Mitochondria, oxidants, and aging. Cell, 120, 483-495

4. Sohal RS, Weindruch R (1996) Oxidative stress, caloric restriction, and aging. Science, 273, 59-63

5. Davies KJ (2000) Oxidative stress, antioxidant defenses, and damage removal, repair, and replacement systems. IUBMB Life, 50, 279-289

6. Medzhitov R (2008) Origin and physiological roles of inflammation. Nature, 454, 428-435

7. Guha M, Mackman N (2001) LPS induction of gene expression in human monocytes. Cell Signal, 13, 85-94

8. Coussens LM, Werb Z (2002) Inflammation and cancer. Nature, 420, 860-867

9. Posadas I, Terencio MC, Guillén I, Ferrándiz ML, Coloma J, Payá M, Alcaraz MJ (2000) Co-regulation between cyclo-oxygenase- 2 and inducible nitric oxide synthase expression in the time-course of murine inflammation. N-S Arc Pharmacol, 361, 98-106

10. Cencioni C, Spallotta F, Martelli F, Valente S, Mai A, Zeiher AM, Gaetano C (2013) Oxidative stress and epigenetic regulation in ageing and age-related diseases. Int J Mol Sci, 14, 17643-17663

11. Kundu JK, Surh YJ (2008) Inflammation: gearing the journey to cancer. Mutat Res-Rev Mutat, 659, 15-30

12. Lee TB (1979) Illustrated flora of Korea, Hangmunsa, Seoul, Korea, p 203

13. Jo JS, Hwang SY (1990) Gijeunyungusa, Seoul, Korea, p $154-155$

14. Bozin B, Mimica-Dukic N, Samojlik I, Goran A, Igic $\mathrm{R}$ (2008) Phenolics as antioxidants in garlic (Allium sativum L., alliaceae). J Agric Food Chem, 111, 925-929

15. Lee MK, Park JS, Na HS (2005) Proximate compositions of green garlic powder and microbiological properties of bread with green garlic. Korean J Food Preserv, 12, 95-100

16. Folin O, Denis W (1912) On phosphotungasticphosphomolybetic compounds as color regents. J Biol Chem, 12, 239-249

17. Carmichael J, DeGraff WG, Gazdar AF, Minna JD, Mitchell HB (1987) Evaluation of a tetrazolium based semiautomated colorimetric assay : assessment of chemosensitivity testing. Cancer Res, 47, 936-942

18. Ding AH, Nathan CF, Stueher DJ (1988) Release of reactive nitrogen intermediates and macrophages. Comparison of activation cytokines and evidence for independent production. J Immunol, 141, 2407-2412

19. Duthie G, Crozier A (2000) Plant-derived phenolic antioxidants. Curr Opin Clin Nutr Metab Care, 3, 447-451

20. Ferreres F, Gomes D, Valentao P, Goncalves R, Pio R, Chagas EA, Seabra RM, Andrade PB (2009) Improved loquat (Eriobotrya japonica Lindl.) cultivars : variation of phenolics and antioxidative potential. Food Chem, 114, 1019-1027

21. Kromhout D (1987) Essential micronutrients in relation to carcinogenesis. Am J Clin Nutr, 45, 1361-1467

22. Park SJ, Park DH, Kim SS, Gon J, Lee HY (2009) Chemical compositions of fermented Codonopsis lanceolata. J Food Sci Nutr, 38, 396-400

23. Moon JS, Kim SJ, Par YM, Hwang IS, Kim EY, Park JW, Park IB, Kim SW, Kang WG, Park YK, Jung ST (2004) Antimicrobial effect of methanol extracts from some medicinal herbs and the content of phenolic compounds. Korean J Food Preserv, 11, 207-213

24. Molyneux P (2004) The use of the stable free radical diphenylpicrylhydrazyl (DPPH) for estimating antioxidant activity. Songklanakarin J Sci Technol, 26, 211-219

25. Lu Y, Foo LY (2000) Antioxidant and radical scavenging activities of polyphenols from apple pomace. J Agric Food Chem, 68, 81-85

26. Rice-Evans CA, Miller NJ, Paganga G (1996) Structureantioxidant activity relationships of flavonoids and phenolic acids. Free Radic Biol Med, 20, 933-956

27. Rice-Evans CA, Miller NJ, Bolwell GP, Bramley PM, Pridham JB (1995) The relative antioxidant activities of plant-derived polyphenolic flavonoids. Free Radic Res, 22, 375-383

28. Miller NJ, Sampson J, Candeias LP, Bramley PM, Rice-Evans CA (1996) Antioxidant activities of carotenes and xanthophylls. FEBS Lett, 384, 240-242

29. Weisz A, Cicatiello L, Esumi H (1996) Regulation of the mouse inducible-type nitric oxide synthase gene promoter by interferongamma, bacterial lipopolysaccharide and NG-monomethyl-L-arginine. Biochem J, 316, 209-215

30. An SM, Kim HG, Choi EJ, Hwang HH, Lee ES, Baek JH, Boo YC, Koh JS (2014) Screening for antiinflammatory activities in extracts from Korean herb 
medicines. J Soc Cosmet Scientists Korea, 40, 95-108

31. Kang CH, Choi YH, Choi IW, Lee JD, Kim GY (2011) Inhibition of lipopolysaccharide-induced iNOS, COX-2, and TNF-a expression by aqueous extract of Orixa japonica in Raw 264.7 cells via suppression of NF- $\kappa \mathrm{B}$ activity. Trop J Pharm Res, 10, 161-168

32. Shon MS, Song JH, Kim JS, Jang HD, Kim GN (2013) Anti-oxidant activity of oil extracted from Korean red ginseng and its moisturizing function. Korean J Aesthet Cosmetol, 11, 489-494

33. Lee HJ, Sim BY, Bak JW, Kim DH (2014) Effect of Gami-sopungsan on inflammation and DNCB-induced dermatitis in NC/Nga in mice. Korean J Orient Physiol Pathol, 28, 146-153

34. Kuo, Li C, Chi CW, Liu TY (2004) The antiinflammatory potential of berberine in vitro and in vivo. Cancer letters, 203, 127-137

35. Nilsson G, Svensson V, Nilsson K (1995) Constitutive and inducible cytokine mRNA expression in the human mast cell line HMC-1. Scand J Immunol, 42, 76-81

36. Papanicolaou DA, Wilder RL, Manolagas SC, Chrousos GP (1998) The pathophysiologic roles of interleukin-6 in human disease. Ann Intern Med, 128, 127-137
37. Zhang Y, Ramos BF, Jakschik BA (1992) Neutrophil recruitment by tumor necrosis factor from mast cells inimmune complex peritonitis. Science, 258, 1957-1959

38. Roitt I, Brostoff J, Male D (2002) Immunology, 6th ed, London : Mosby

39. Hur GM, Ryu YS, Yun HY, Jeon BH, Kim YM, Seok JH, Lee JH (1999) Hepatic ischemia/reperfusion in rats induces iNOS gene transcription by activation of NF-kappaB. Biochem Biophys Res Commun, 261, 917-922

40. Sato T, Nakajima H, Fujio K, Mori Y (1997) Enhancement of prostaglandin E2 production by epidermal growth factor requires the coordinate activation of cytosolic phospholipase A2 and cyclooxygenase 2 in human squamous carcinoma A431 cells. Prostaglandins, 53, 355-369

41. Huang M, Stolina M, Sharma S, Mao JT, Zhu L, Miller PW, Dubinett SM (1998) Non-small cell lung cancer cyclooxygenase-2-dependent regulation of cytokine balance in lymphocytes and macrophages : up-regulation of interleukin 10 and down-regulation of interleukin 12 production. Cancer Res, 58, 1208-1216 